УДК 553.98.04

НЕФТЬ И ЭКОСИСТЕМА КАСПИЙСКОГО МОРЯ

\title{
OIL AND CASPIAN SEA ECOSYSTEM
}

\author{
М.ШІ. Арабов \\ Астраханский государственный технический университет, \\ г. Астрахань, Российская Федерация \\ 3.M. Арабова
}

Институт геохимии и аналитической химии им. В.И. Вернадского Российской академии наук, г. Москва, Российская Федерация

Mikhail S. Arabov

Astrakhan State Technical University, Astrakhan, Russian Federation

\section{Zarema M. Arabova}

Vernadsky Institute of Geochemistry and Analytical Chemistry

of Russian Academyy of Sciences,

Moscow, Russian Federation

e-mail: arabov57@mail.ru

Аннотация. Каспийское море считается самым большим озером на Земле. Оно не имеет поверхностного или подземного стока и граничит между Европой и Азией. В Каспийское море впадает более 130 рек, в том числе и Волга, связывающая его с Мировым океаном. На дне Каспийского имеются несметные богатства нефтяных ресурсов. Предварительные данные геологоразведки показывают, что в недрах морского дна сосредоточено более чем в 3 раза больше углеводородов, чем на суше. 
Вследствие этого в обозримом будущем нефть заменить будет нечем. Мировой спрос будет расти на 1,5 \% в год, а предложение существенно не возрастет, что со временем может привести к очередному мировому энергетическому кризису. Современный образ жизни человека в комфортных условиях напрямую связан с добычей и переработкой нефти и газа. В данной статье описано влияние добычи нефти и газа на экосистему Каспийского моря. Важным фактором для добычи нефти на дне Каспийского моря является разумное совмещение интересов нефтедобычи и сохранение биологических ресурсов, таких как: ценные виды рыб (осетровые - $90 \%$, сельдь и др.), миллионы водоплавающих и околоводных птиц, а также около 400 видов эндемичных животных. В статье также рассмотрены вопросы сохранения существующей биосистемы, требующие комплексного подхода.

Abstract. The Caspian Sea is considered the largest lake on Earth. It has no surface or underground runoff and is bordered by Europe and Asia. More than 130 rivers flow into the Caspian Sea, including the Volga, connecting it with the World Ocean. At the bottom of the Caspian there are innumerable wealth of oil resources. Preliminary exploration data show that more than 3 times more hydrocarbons are concentrated in the bowels of the seabed than on land. As a result, there will be nothing to replace oil in the foreseeable future. Global demand will grow by $1.5 \%$ per year, and supply will not increase significantly, which over time can lead to another global energy crisis. The modern lifestyle of a person in comfortable conditions is directly related to the production and processing of oil and gas. This article describes the impact of oil and gas production on the ecosystem of the Caspian Sea. An important factor for oil production at the bottom of the Caspian Sea is a reasonable combination of oil production interests and the preservation of biological resources, such as: valuable fish species (sturgeon - $90 \%$, herring, etc.), millions of waterfowl and near-water birds, as well as about 400 species of endemic animals . The article 
considers the issues of conservation of the existing biosystem, requiring an integrated approach.

Ключевые слова: Каспийское море; добыча нефти и газа; загрязнение воды; каспийская экосистема

Key words: Caspian sea; oil and gas production; water pollution; Caspian ecosystem

\section{Введение}

В последние годы человечеству пришлось столкнуться с такими явлениями, как:

1. Увеличение численности людей. За последние десять лет прирост народонаселения составил около 85-90 млн/год, а в июне 2018 г. общее количество людей, живущих на планете Земля, достигло цифры 7,6 млрд человек. Особенно бурное увеличение народонаселения Земли произошло за последние 100 лет (от 1900 г. до 2000 г.). В этот период население земного шара увеличилось в 4 раза: с 1,5 млрд до 6,1 млрд.

2. Истощение запасов углеводородов на старых месторождениях. Данный фактор сподвиг нефтяников на освоение углеводородов на дне Каспийского моря.

Нефть - это валюта для государства, источник углеводородного сырья, из которого получают разнообразные вещества: топливо (бензин, керосин, лигроин, мазут, дизельное топливо, гудрон и т.д.), лекарственные препараты, бытовую химию, различные удобрения, пластмассы, ткани, резину, краски, каучук, вазелин, теплоносители, хладагенты и т.д. Иными словами, нефть вошла в нашу жизнь настолько, что порой мы не замечаем это, воспринимая как само собой разумеющееся, в результате чего наша современная комфортная жизнь невозможна без нее. 
Поэтому разработка морских нефтегазовых ресурсов для прибрежных стран является объективной необходимостью и альтернативой для развития региона, страны. Постановление совета министров РСФСР от 31 января 1975 г. N 78 «Об объявлении заповедной зоны в северной части Каспийского моря» на какое-то время задержало поиски и добычу углеводородов на севере Каспийского моря, но не остановило объективный ход истории, и уже 19 декабря 1997 г. ООО «ЛУКОЙЛ» получило лицензию на право для поиска, разведки и добычи углеводородов на Каспийском море.

Для добычи нефти на Каспийском море очень важным является разумное совмещение интересов нефтедобычи и сохранение биологических ресурсов, так как:

- около 40 видов фауны рыб на Каспии имеют промысловое значение (осетровые - 90 \% мирового улова, килька, окунь, сельдь и другие виды ценных рыб) [1];

- 400 видов эндемичных животных и в том числе эндемика Каспийского тюленя;

- миллионы водоплавающих, околоводных птиц, обитающих постоянно или в периоды сезонных миграций и зимовки.

\section{Проблемы сохранения и охраны экосистемы Каспийского моря}

На самом деле, проблемы сохранения и охраны исторически сложившейся экосистемы (чистоты вод Каспийского моря) существовали еще в Советское время и, прежде всего, к ним относят:

1. Бурный рост городов вдоль побережья Каспийского моря и вдоль крупных рек, таких как Волга, Урал, Терек, Кура (где действовали десятки промышленных предприятий), в которых не было системы очистки сточных вод (а если и были, то эти очистные сооружения работали чисто символически - не эффективно) - десятилетиями в море уходили сотни тонн химически вредных веществ. Поэтому естественным было снижение 
из года в год улова ценных видов рыб. По различным причинам в акваторию Каспийского моря с речными и прибрежными водами ежегодно в Каспийское море попадает около $70000-90000$ т углеводородов, промотходов, а с побережий - 29000 т. Безусловно, все перечисленное не способствует сохранению исторически существующих экосистем.

2. Периодические, достаточно резкие колебания уровня моря (более 2,5 м/год) приводят к деградации прибрежных экосистем. В одно время это связывали с отбором воды на орошение сельхозугодий с крупных рек, однако позже выяснилось, что это не совсем так. Теперь предполагаем, что это связано с высокой сейсмической неустойчивостью дна Каспийского моря.

Безусловно, сохранению исторически сложившейся экосистемы Каспийского моря не способствовало «дикое» браконьерство 90-х годов ХХ века, большое количество вновь родившихся туристических баз и бесконтрольное (бесчисленное) количество «маломерного флота» с моторами мощностью свыше 20 л.с. в заповедных зонах прибрежных государств.

Развал СССР привел к тому, что новые независимые прикаспийские государства, для того чтобы как-то выйти из кризиса, вынуждены были привлечь инвестиции транснациональных нефтяных компаний и порою на их условиях начинать поиск и добычу нефти на Каспийском море.

Учитывая разведанные запасы месторождений нефти и газа на дне Каспийского моря (более 10 млрд т, а в Персидском заливе - более 20 млрд т), можно констатировать факт, что Каспийское море стало одним из ведущих регионов мира, добывающих, подготавливающих и транспортирующих углеводороды в различные страны мира [2, 3].

В Российском секторе добычи углеводородов ООО «ЛукойлНиженволжскнефть» достаточно жестко соблюдается принцип «нулевого сброса» и выполняются взятые обязательства по соблюдению 
экологических норм: все промотходы (в том числе и выбуренная порода) собираются в контейнеры и вывозятся судами в Астрахань на утилизацию.

Тем не менее, Каспийское море не защищено от экологических катастроф, человеческого фактора. Дно Каспийского моря - это участок с высокой сейсмической неустойчивостью. Прокладка нефтегазопроводов связана с большими рисками (при разрыве нефтегазопровода с высоким содержанием сероводорода - концентрация сероводорода на промыслах Казахстана до $40 \%$ или при разгерметизации обсадных колонн нефтедобывающих скважин) может привести к экологической катастрофе на Каспийском море, учитывая его закрытый характер.

Так, например, в 2000 г. из-за попадания большого количества углеводородов в море в районе нефтегазовых промыслов Казахстана погибло огромное количество тюленей (свыше 50 тыс.), ценных рыб, и в том числе осетровых. Как бы не заявляли прибрежные государства о защите природных ресурсов Каспийского моря, но фактом остается, что ПДК по углеводородам в зоне Бакинского архипелага и Апшеронского полуострова находится в пределах 8000 ПДК и однозначно можно сказать, что вышеназванный район Каспийского моря утерян для рыбного хозяйства.

Площадь Каспийского моря огромна - около 371000 км², и на этой площади все еще существуют районы для самоочищения и саморегуляции экосистем.

\section{Вывод}

Важно отметить, что каспийское море - это уникальная, достаточно ранимая биосистема, и вопросы сохранения существующей биосистемы требует комплексного подхода и соблюдения, общих правил всеми прикаспийскими странами по использованию его недр и богатств. 


\section{Список используемых источников}

1. Ходоревская Р.П., Калмыков В.А., Жилкин А.А. Современное состояние запасов осетровых Каспийского бассейна и меры по их сохранению // Вестник Астраханского государственного технического университета. Серия: Рыбное хозяйство. 2012. № 1. С. 99-106.

2. Гулиев И.С., Кулаков С.И., Федоров Д.Л. Нефтегазоносность Каспийского региона. Баку: Nafta-Press, 2009. 409 с.

3. Глумов И.Ф., Маловичкий Я.П., Новиков А.А., Сенин Б.В. Региональная геология и нефтегазоносность Каспийского моря. М.: НедраБизнесцентр, 2004. 342 с.

\section{References}

1. Khodorevskaya R.P., Kalmykov V.A., Zhilkin A.A. Sovremennoe sostoyanie zapasov osetrovykh Kaspiiskogo basseina i mery po ikh sokhraneniyu [Present State of Caspian Sturgeon Reserves and Measures on its Conservation]. Vestnik Astrakhanskogo gosudarstvennogo tekhnicheskogo universiteta. Seriya: Rybnoe khozyaistvo - Vestnik of Astrakhan State Technical University. Series: Fishing Industry, 2012, No. 1, pp. 99-106. [in Russian].

2. Guliev I.S., Kulakov S.I., Fedorov D.L. Neftegazonosnost' Kaspiiskogo regiona [Oil and Gas Potential of the Caspian Region]. Baku, Nafta-Press Publ., 2009. 409 p. [in Russian].

3. Glumov I.F., Malovichkii Ya.P., Novikov A.A., Senin B.V. Regional'naya geologiya $i$ neftegazonosnost' Kaspiiskogo morya [Regional Geology and Oil and Gas Potential of the Caspian Sea]. Moscow, NedraBiznestsentr Publ., 2004. 342 p. [in Russian]. 


\section{Сведения об авторах}

\section{About the authors}

Арабов Михаил Шугеевич, канд. хим. наук, доцент кафедры «Технологические машины и оборудование», Институт нефти и газа, Астраханский государственный технический университет, г. Астрахань, Российская Федерация

Mikhail S. Arabov, Candidate of Chemical Sciences, Assistant Professor of Technological Machines and Equipment Department, Institute of Oil and Gas, Astrakhan State Technical University, Astrakhan, Russian Federation e-mail: arabov57@mail.ru

Арабова Зарема Михайловна, младший научный сотрудник, Институт геохимии и аналитической химии им. В.И. Вернадского Российской академии наук, г. Москва, Российская Федерация

Zarema M. Arabova, Junior Researcher, Vernadsky Institute of Geochemistry and Analytical Chemistry of Russian Academyy of Sciences, Moscow, Russian Federation

e-mail: zarema.polymer@gmail.com 